\title{
The application of direct smelting of gold concentrates as an alternative to mercury amalgamation in small-scale gold mining operations in Ghana
}

\author{
R.K. Amankwah* \\ P.O. Box 237, Tarkwa, Ghana \\ ${ }^{*}$ Corresponding author

\section{M.T. Styles} \\ British Geological Survey, \\ Keyworth, Nottingham, \\ NG12 5GG, UK \\ E-mail:mts@bgs.ac.uk
}

University of Mines and Technology,

E-mail: rkamankwah@umat.edu.gh

\section{R.S. Nartey and S. Al-Hassan}

University of Mines and Technology, P.O. Box 237, Tarkwa, Ghana

E-mail: rsnartey@umat.edu.gh

E-mail: salhassan@umat.edu.gh

\begin{abstract}
Mercury is used in small-scale mining to amalgamate gold particles, facilitating their separation from heavy sands. The negative environmental/health-related effects of mercury in mining communities in Ghana and other countries have generated research interest into development of safer alternatives. This study tested direct smelting as an alternative to amalgamation. In laboratory investigations, direct smelting yielded $99.8 \%$ recovery against $97 \%$ for amalgamation. A locally-fabricated furnace, sika bukyia, was used in field tests, yielding an average recovery of $98.3 \%$ compared to $88 \%$ for amalgamation. Direct smelting has the potential to replace amalgamation and retorting because it is effective, easy, quick and transparent.
\end{abstract}

Keywords: smelting; small-scale mining; gold; mercury; Ghana.

Reference to this paper should be made as follows: Amankwah, R.K., Styles, M.T., Nartey, R.S. and Al-Hassan, S. (xxxx) 'The application of direct smelting of gold concentrates as an alternative to mercury amalgamation in small-scale gold mining operations in Ghana', Int. J. Environment and Pollution, Vol. x, No. x, pp.xxx-xxx.

Biographical notes: Richard K. Amankwah is Associate Professor in Mineral Engineering at the University of Mines and Technology (UMaT),

Tarkwa, Ghana. He was educated at The Kwame Nkrumah University of 
Science and Technology, Technical University of Clausthal, Germany, and Queen's University, Canada, where he obtained a $\mathrm{PhD}$ in 2005. His current research areas include bio-hydrometallurgy, environmental biotechnology, the application of microwaves in extractive metallurgy, occupational health and safety, and small-scale gold mining. He is a member of the Ghana Institution of Engineers (GIE), and Society for Mining, Metallurgical and Exploration Engineers (SME).

Robert S. Nartey has been a lecturer at the University of Mines and Technology (UMaT) since 1999, after graduating from New Mexico Tech, USA, in 1998. $\mathrm{He}$ has been an active member of research teams in the university and has provided consultancy services in mineral exploration to several mining companies over the years. His research interests are in mineral exploration, exploration geochemistry, environmental and mining geology, industrial minerals and small-scale mining. He is a member of the Society of Economic Geologists (SEG) and Ghana Institution of Geoscientists (GhIG).

S. Al-Hassan is an Associate Professor in Mining Engineering at the University of Mines and Technology (UMaT), Tarkwa, Ghana. He obtained his BSc (Hons) and Postgraduate Diploma in Mining Engineering from the Kwame Nkrumah University of Science and Technology in 1982 and 1983, respectively, and a PhD in 1994 from the University of Wales, Cardiff, UK. He worked as a Mining Engineer at Tarkwa Goldfields Ltd until 1987, when he joined UMaT. His areas of specialisation include mineral reserve estimation, mine planning and design, mineral economics and computer applications.

Mike Styles is a principal geologist at the British Geological Survey. He has a long interest in gold exploration and the mineralogy of gold. He developed techniques for estimating the sources of alluvial gold and in the course of this, an interest in artisanal gold mining. He has worked on projects covering technical assistance to small-scale mining in Africa, South America and South-East Asia. These have largely been based on simple, appropriate, improvements to technology but allied to this, decreasing the harmful impact of small-scale mining operations.

\section{Introduction}

In small-scale gold mining around the world, mercury is used to recover gold particles from concentrates. It is added during comminution, gravity concentration or more commonly after gravity concentration, when the gold is concentrated along with heavy black sands. During amalgamation, mercury is added to the gold concentrate and agitated vigorously to force it and gold particles to make contact, which results in a pasty amalgam. This is subsequently separated from the black sands and after 'squeezing' out excess mercury, the amalgam is often heated in the open air to obtain 'sponged' gold. Mercury is lost in the process either as globules due to spillage and careless disposal of amalgamation residues, as well as in gaseous form, released during the heating of the amalgam.

In Ghana small-scale gold mining has contributed immensely to the national economy: between 1989, when it was officially legalised in the country, through to 2008, it accounted for the production over three million ounces of gold. This production accounted for over US\$500 million; the sector currently accounts for $16 \%$ of national 
gold output (Anon, 2009; Cleland, 2008). The rise in production in the sector has also resulted in increased use of mercury. It is estimated that for every gram of gold recovered by ASM, there is an equivalent amount of mercury lost to the environment. Thus, for the period under consideration, about three million ounces (93 tonnes) of mercury has been discharged into the environment due to ASM activities.

Mercury is a toxic metal and when methylated, it becomes extremely toxic. Its impacts on the environment and human health in communities where small-scale gold mining flourishes have been documented. Work undertaken in sub-Saharan Africa, Asia and Latin America shows that in small-scale mining communities, both miners and non-miners are exposed to mercury to varying degrees of exposure and contamination (Appleton et al., 1999; Anon, 1999; Drasch et al., 2001; Babut et al., 2003; Serfor-Armah et al., 2004; Tschakert and Singha, 2007; Hilson et al., 2007). Ghana has been particularly affected, as illustrated by a recent study conducted in Dumasi, an ASM community (Babut et al., 2001, 2003). The analysis determined that $20 \%$ of sampled persons had tremors and $65 \%$ had sleep disorders. Examination of mercury in biological samples indicated that between $86 \%$ and $91 \%$ of people tested had varying levels of mercury intoxication and that the metal is having an impact on the public health of the ASM community.

In response to levels of mercury intoxication recorded in studies in small-scale mining centres around the world, several interventions have been made with the aim of reducing its usage and losses to the environment. Some of the methods that have been prescribed include winnowing, the coal gold agglomeration process, smelting, and leaching processes such as IGoli, Haber and cyanidation. Coal-gold agglomeration is a physical-chemical process that utilises pulverised coal for the agglomeration of fine gold particles, followed by flotation with diesel, kerosene and other oils (Hilson and Monhemius, 2006). The float concentrate has to be processed and smelted. On the other hand, IGoli, Haber and cyanidation processes utilise leaching reagents to dissolve gold and solutions have to be processed further for gold recovery. The small-scale mining law in Ghana does not permit the leaching of gold due to the harmful nature of the chemicals involved and the low safety consciousness of the miners. Thus, for now, none of these chemical processes can be applied. Direct smelting, on the other hand, could generate a final product in one step, and is something with which miners are already familiar because they smelt sponge gold after amalgamation and retorting/heating (Anon, 2003; Styles et al., 2009).

The Ghana Mercury Pollution Abatement Project was implemented by the European Union in 2006. Its purpose was to review the mining and processing methods utilised by small-scale miners in Ghana, and to develop an alternative method for extracting gold from concentrates without the use of mercury. Findings from research undertaken during the first phase of the project, reported by Styles et al. (2009) in this issue, revealed that miners would accept any method that was inexpensive, fast, easy to use, transparent and suitable for small batches.

The first phase of the study also identified direct smelting of gold concentrates as a method that could potentially replace mercury amalgamation and retorting. In the second phase, described in this paper, direct smelting was tested at both the bench scale in the laboratory and in the field. The target was to test direct smelting and 
1 develop a suitable flux composition for the types of concentrates that are obtained by the miners

2 compare amalgamation and smelting in terms of time utilised and gold recovery

3 design and construct furnaces using local materials that could be used by small-scale miners to smelt concentrates

4 investigate fuels that could be used in smelting.

\section{Experimental investigation}

\subsection{Sampling}

Five samples were collected from cross-sections of the various gold belts of Ghana for this study. Of the five samples, two were sulphidic, two were free milling and one was of alluvial origin. One of both of the sulphidic and free milling samples was taken from the Tarkwa area in Southern Ghana and the others from Bolgatanga in the Upper East Region. The alluvial ore was obtained from Bonte, in the South-Central part of Ghana. The locations of the areas where samples were taken are shown in Figure 1.

Figure 1 Geological map of Ghana showing the location of gold-bearing areas and the places where samples were collected (see online version for colours)

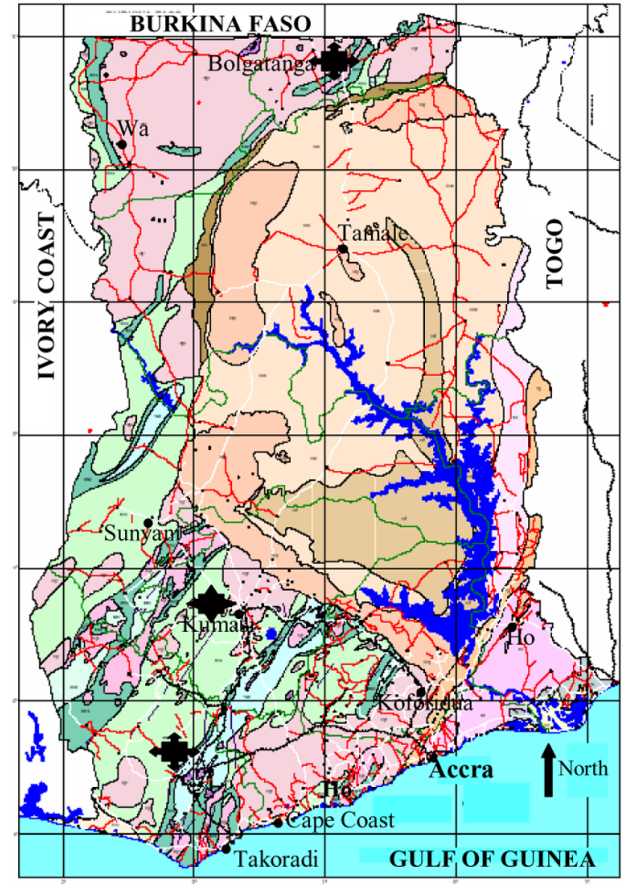

Source: Adapted from Anon (2008)
Upper Birimian

Lower Birimian

Tarkwaian (Banket)

Granite

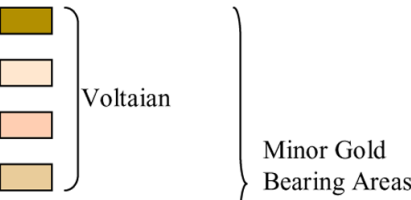

Dahomeyan

Togo Series

Buem Tectonic

Unit

Areas where samples were taken 


\subsection{Sample preparation and laboratory analysis}

The hard rock samples were passed through primary crushing in a hammer mill, followed by dry grinding in a disc mill and screen analysis showed that $80 \%$ of the product was finer than $250 \mu \mathrm{m}$. The milled samples were sluiced and the rougher concentrate collected. After several batches of the material had been sluiced, the rougher concentrate was cleaned in a pan in order to estimate the free gold content. The alluvial sample did not go through comminution but was sluiced after scrubbing and screening.

Five, $8 \mathrm{~kg}$ gold-containing black sand samples, obtained following gravity concentration, were used to investigate and establish the efficiency of direct smelting of black sands compared with amalgamation followed by retorting and smelting. Samples were split into four and each was cleaned on a shaking table. The cleaned concentrate was re-cleaned on a pan to obtain a maximum final weight of $50 \mathrm{~g}$. A flowsheet of the work scheme is presented in Figure 2.

Figure 2 Flowsheet showing the steps involved in the analyses

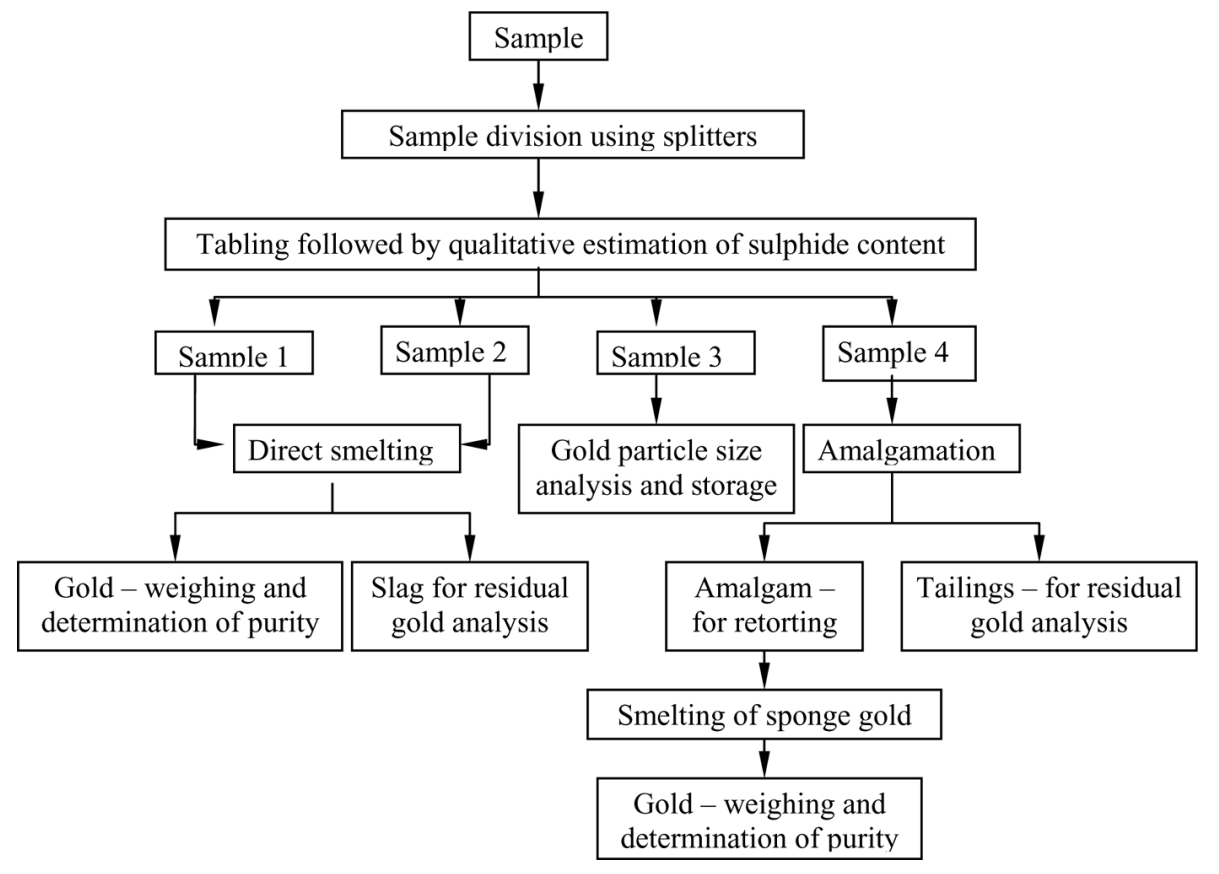

Amalgamation was carried out by introducing mercury into bottles containing black sands. The bottles were subsequently agitated for $20 \mathrm{~min}$ before separation of the amalgam. Retorting was carried out in a ThermEx glass retort ${ }^{1}$ and heating was carried out for about $90 \mathrm{~min}$. The sponge gold obtained was smelted with borax, a low melting point flux, while residual gold in the barren black sands was determined by conventional fire assaying. Two sub-samples of the final concentrates were dried, fluxed and smelted. Gold was finely divided in these samples and smelting was conducted at $1100^{\circ} \mathrm{C}$ in a laboratory furnace. The flux consisted of sodium tetraborate (borax), sodium carbonate (soda ash) and potassium nitrate (nitre) but the actual flux composition utilised for each sample depended on its sulphur and iron content. 
One sub-sample was amalgamated while the fourth was kept as a reference sample which could be used if problems were encountered during processing of the others. The tailings obtained from each of the three samples processed by either amalgamation or direct smelting were analysed for gold by conventional fire assaying.

\subsection{Field trials}

Field investigations were conducted for both direct smelting, and amalgamation and heating methods. No special equipment was required for amalgamation and retorting, as the standard technique used by the miners was tested. A smelting furnace, called sika bukyia, was constructed and tested for smelting of gold concentrates produced from small-scale mining operations. The furnace (Figure 3) has a steel shell and a heating chamber lined with refractory bricks. The external dimensions of the furnace are $50 \mathrm{~cm} \times 35 \mathrm{~cm}$ and the combustion chamber has dimensions $37 \mathrm{~cm} \times 23 \mathrm{~cm}$. Because of the size of the combustion chamber, it can accommodate two smelting crucibles. A removable chimney equipped with an electric fan extracts flue gases from the heating chamber and away from the operator. With the chimney on, the furnace stands at $206 \mathrm{~cm}$. The initial fuels used were wood charcoal and palm kernel shell.

Figure 3 A picture of the sika bukyia (see online version for colours)

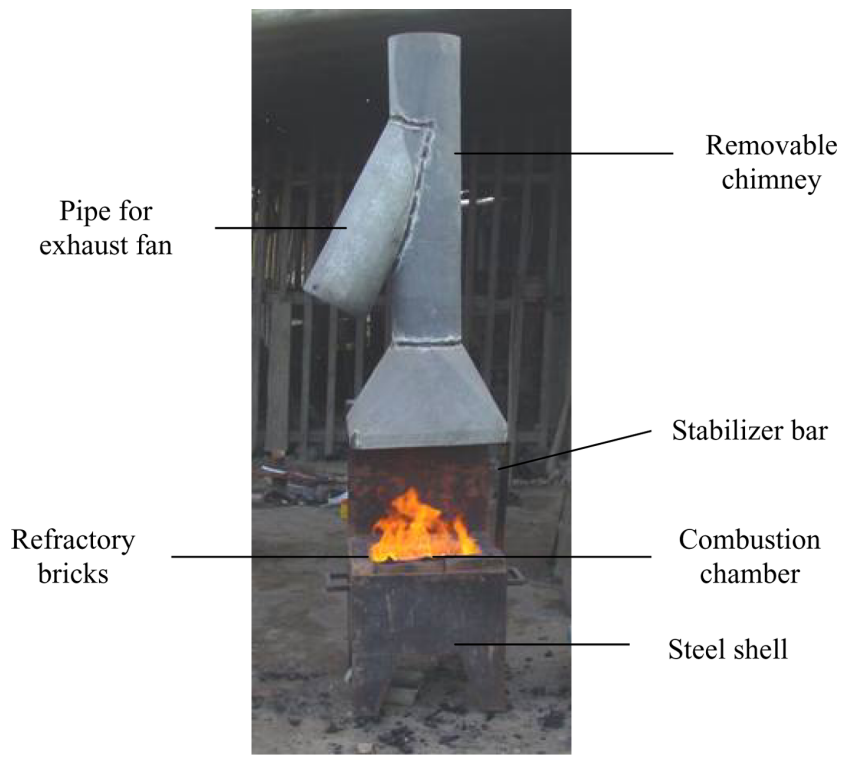

\section{Results and discussion}

\subsection{Direct smelting vs. amalgamation and retorting}

In this study, gold recovery by direct smelting of concentrates and that via amalgamation, retorting and smelting were compared in terms of recovery and time utilised for the operation. Laboratory investigations conducted on alluvial, free milling and sulphidic ores indicated recovery of about $99 \%$ for direct smelting. Under controlled laboratory 
conditions, amalgamation was carried out in shake bottles for $20 \mathrm{~min}$ using a shaking machine. This is definitely more effective than rubbing the sands with bare fingers as is the practice among small-scale miners. This yielded a minimum recovery of $95 \%$ (Tables 1 and 2), which is certainly higher than the standard ASM practice.

Table 1 Results of samples treated by amalgamation followed by retorting and smelting

\begin{tabular}{lcccccc}
\hline & $\begin{array}{c}\text { Weight of } \\
\text { sponge } \\
\text { gold }(\mathrm{g})\end{array}$ & $\begin{array}{c}\text { Weight of } \\
\text { smelted } \\
\text { gold }(\mathrm{g})\end{array}$ & $\begin{array}{c}\text { Specific } \\
\text { gravity }\end{array}$ & $\begin{array}{c}\text { Actual } \\
\text { gold }(\mathrm{g})\end{array}$ & $\begin{array}{c}\text { Gold in } \\
\text { tailings }(\mathrm{g})\end{array}$ & $\begin{array}{c}\text { Recovery } \\
(\%)\end{array}$ \\
\hline Alluvial & 1.06 & 0.97 & 19.25 & 0.9675 & 0.0020 & 99.8 \\
Free milling ore 1 & 5.72 & 5.20 & 18.95 & 5.1057 & 0.0609 & 98.8 \\
Free milling ore 2 & 0.12 & 0.10 & 19.20 & 0.0995 & 0.0029 & 97.2 \\
Sulphidic ore 1 & 1.11 & 1.08 & 19.20 & 1.0744 & 0.0122 & 98.9 \\
Sulphidic ore 2 & 1.41 & 1.30 & 18.57 & 1.2508 & 0.0604 & 95.4 \\
\hline
\end{tabular}

Table 2 Results of samples treated by direct smelting

\begin{tabular}{lccccc}
\hline Sample & $\begin{array}{c}\text { Weight of } \\
\text { smelted gold }(\mathrm{g})\end{array}$ & $\begin{array}{c}\text { Specific } \\
\text { gravity }\end{array}$ & $\begin{array}{c}\text { Actual } \\
\text { gold }(\mathrm{g})\end{array}$ & $\begin{array}{c}\text { Gold in } \\
\text { tailings }(\mathrm{g})\end{array}$ & $\begin{array}{c}\text { Recovery } \\
(\%)\end{array}$ \\
\hline Alluvial & 0.93 & 19.25 & 0.9276 & 0.0002 & 99.98 \\
Free milling ore 1 & 4.32 & 19.20 & 4.2976 & 0.0016 & 99.96 \\
Free milling ore 2 & 2.08 & 19.26 & 2.0757 & 0.0008 & 99.96 \\
Sulphidic ore 1 & 2.49 & 19.25 & 2.4835 & 0.0006 & 99.98 \\
Sulphidic ore 2 & 3.86 & 19.20 & 3.8400 & 0.0008 & 99.97 \\
\hline
\end{tabular}

Field tests were conducted on ten samples for both direct smelting and amalgamation, yielding a recovery of $98 \%$ for the former and $88 \%$ for the latter. It was observed that gold particles coated with iron oxides were not incorporated into the amalgam, and fine gold particles were lost when excess mercury is squeezed through the fabric. Direct smelting is not well-suited for samples with very low gold content. For efficient smelting and easy separation of gold bead from the slag, the weight of gold in the concentrate should be about $0.5 \mathrm{~g}$. Figure 4 illustrates how gold separates from the slag after smelting.

Figure 4 Separation of gold from slag (see online version for colours)

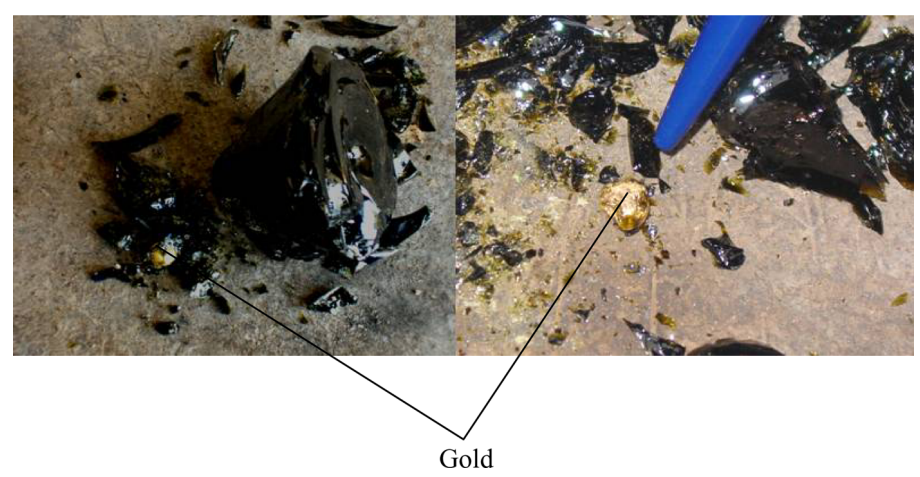


The flowsheet in Figure 2 shows that processing of gold concentrates using amalgamation, retorting and smelting involves four steps while that by direct smelting involves two. The possible time savings from direct smelting could be appealing to the miners. Field trials by the authors indicate that amalgamation may be conducted for between $15 \mathrm{~min}$ and $45 \mathrm{~min}$, depending on the amount of gold concentrate. About $5 \mathrm{~min}$ is spent on heating the amalgam, and another 10-15 min on smelting the sponge gold, which makes the process quite time-consuming and bringing the total time spent up to $65 \mathrm{~min}$. Since the smelt house will be some distance away from the gravity separation unit, some more time is utilised in transporting the sponge gold. Sample preparation and preheating for direct smelting took $10 \mathrm{~min}$, while smelting took up to $35 \mathrm{~min}$, a combined total of $45 \mathrm{~min}$. Thus, there are savings in time with direct smelting and it can all be carried out in one location.

\subsection{Fuels used in direct smelting}

The use of charcoal, although regarded as both cheap and easily accessible by small-scale miners, has an environmental impact. It is, therefore, desirable to identify and test alternative fuels that could replace charcoal but maintain its strong points (cheap, easily accessible, high calorific value and environmentally friendly). Palm kernel shells were identified as one of these alternative fuels. The shells are available around the country, except in the north, and are discarded as waste by local palm oil processors, by itself a situation that is of concern to environmentalists. As such, the use of this as an alternative fuel would have a positive environmental impact and at the same time, provide miners with an efficient fuel that is cheaper and which has a high calorific value necessary for smelting.

In a manner similar to smelting with charcoal, complete smelting was achieved within $45 \mathrm{~min}$, after which, the crucible was removed and the molten material was poured into a mould and allowed to cool. The purity of gold obtained this way was comparable to that obtained when charcoal was utilised. Due to the smaller sizes of the shells, it was necessary to reduce the airflow rate into the combustion chamber to prevent the particles from being blown out of the furnace. The temperature profile of both charcoal and kernel shells are shown in Figure 5.

Figure 5 Temperature profiles for both charcoal and palm kernel shells

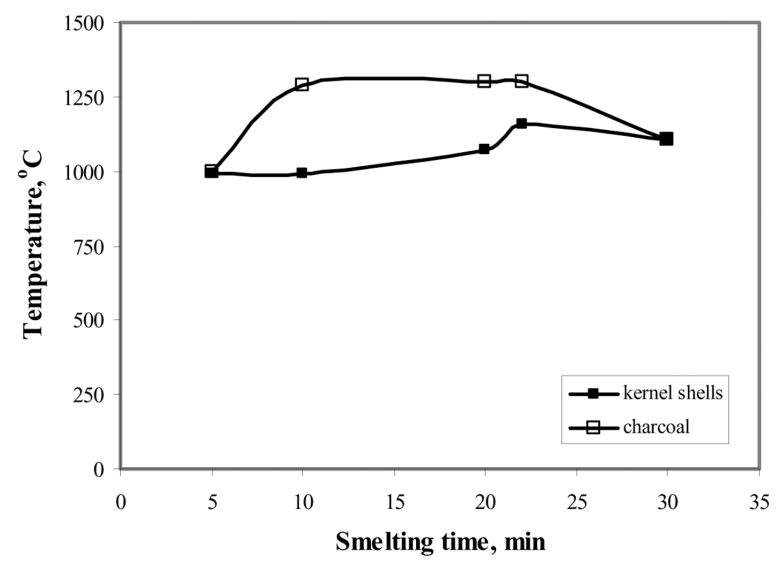


The temperature profile indicates that charcoal generates a much higher and steady temperature than the kernel shells. In addition, charcoal creates a more stable bed for the crucibles throughout the smelting period. Though melting of the charge was achieved with both fuels, the relatively low measured temperature may be due to a lower fuel density and higher heat loss associated with the use of kernel shells. As shown in Figure 6, the flames generated during initial combustion were very intense and sufficiently high enough to pass through the chimney, and is often accompanied by thick smoke. It is likely that this is due to the higher volatile content of the kernel shells. These initial tests show that kernel shells are useable but are not as effective as charcoal. It is possible that performance could be enhanced by simple crushing and pelletising. In both cases, a maximum of $12 \mathrm{~kg}$ of fuel was required for a complete smelting operation. Other fuels such as Liquefied Petroleum Gas (LPG), shea butter waste and saw dust have been identified but yet to be tested.

Figure 6 Intense flames generated by the combustion of kernel shells (see online version for colours)

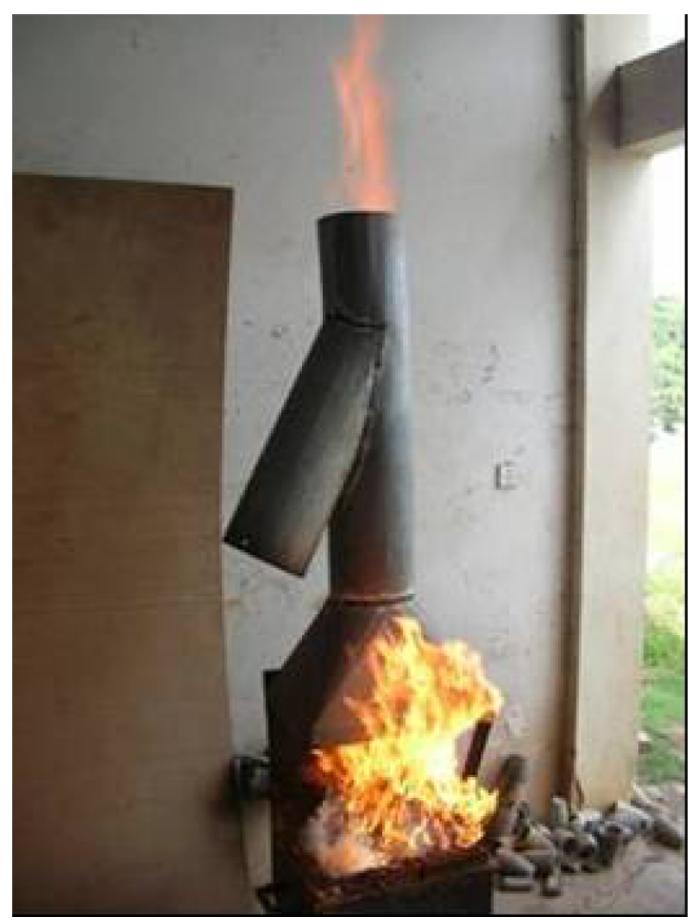

\subsection{Smelting of sulphide concentrates}

It is necessary for sulphide minerals in the concentrate to be oxidised either before or during smelting. Nitre is used in the smelting of sulphidic concentrates and acts as an oxidising agent. It was observed that the addition of this chemical causes excessive boiling of the molten material with the possibility of spillage. Optimisation tests indicated that the maximum amount of nitre necessary to prevent excessive boiling and spillage was not enough to oxidise sulphides, therefore resulting in low purity of the gold bullion. An alternative method, pre-smelting oxidation, was adopted. This involved roasting 
of the concentrate on the hot charcoal in the combustion chamber of the furnace. For the standard weight of sample, $50 \mathrm{~g}$, up to $10 \mathrm{~min}$ roasting was found to be suitable.

It was observed that after roasting, gold included in the sulphide particles was released and reported as part of the bullion. Indeed, when weighed amounts of gold were used in seeding such concentrates, there was an appreciable increase in bullion weight.

\subsection{Economic considerations}

A cost comparison was undertaken for processing $62 \mathrm{~g}$ of gold contained in a concentrate. Field trials indicated that this weight is apparently the maximum amount of gold that can be amalgamated with half a teaspoon of mercury $(27 \mathrm{~g})$. A teaspoon is one of the units in which mercury is sold to small-scale miners. Since the mercury is heated in an open fire, it is lost and the cost can be debited directly to the operation. A similar amount of gold was used in a smelting operation. As shown in Table 3, it costs US\$ 5.50 for amalgamation and heating, while direct smelting cost US\$ 3.20. This makes direct smelting a more economically-viable alternative.

Table 3 Cost comparison between direct smelting and amalgamation followed by heating

\begin{tabular}{lclc}
\hline Amalgamation & Cost $(\$)$ & Direct smelting & Cost (\$) \\
\hline Half teaspoonful of mercury $(27 \mathrm{~g})$ & 4.00 & Crucibles (2) & 3.20 \\
Fuel (charcoal) for heating of amalgam & 0.50 & $\begin{array}{l}\text { (including charcoal for } \\
\text { smelting and flux) }\end{array}$ & \\
Fuel (charcoal) for smelting & 1.50 & & 3.20 \\
Total & 5.50 & & \\
\hline
\end{tabular}

\section{Challenges and ways forward}

A main problem encountered during the field trials was that scavenged concentrates often contained several free metallic components that interfered with smelting, resulting in the production of bullion with very low purity. Moreover, the hammer and disc mills used grinding surfaces that quickly wear and break; as such flakes of steel and other metals become mixed in the concentrate. The metal pieces and filings may be removed with a low intensity magnet but to ensure that most of the metal is removed, this needs to be done carefully and can therefore be quite slow. These concentrates may also be washed with nitric acid to get rid of remaining base metals before smelting. Safety and environmental concerns demand that the operation be conducted in a well ventilated area or fume chamber, and the waste acid neutralised with a base or diluted with large amounts of water before disposal. One major challenge was the failure of crucibles during smelting. Some locally-manufactured crucibles are not competent enough and there was migration of molten material through the crucible walls and in some cases crack formation during smelting. Collaborative research with local crucible manufacturers is ongoing.

Mercury is used to recover gold from concentrates in small-scale gold mining operations but its negative environmental and health impacts has prompted research into safer alternatives. In this study, direct smelting has been tested as an alternative 
to gold extraction by amalgamation and retorting in small-scale gold recovery. Direct smelting has the advantage of recovering gold particles that are occluded in ore particles that report in the concentrate and coated gold particles both of which cannot be picked by mercury. Sulphides in the concentrate will decompose and release the contained gold, and very fine particles that escape during the squeezing of excess mercury from the amalgam will be also be retrieved.

It was realised from the study that direct smelting is a viable option both in the laboratory and in field trials. By using the right combination of borax, soda ash and silica, gold bearing black sands were smelted with relatively high recoveries. Field tests for recovery via amalgamation, heating and smelting gave an average recovery of about $88 \%$ while figures for direct smelting are above $99 \%$. In addition, it takes a shorter time to execute. The furnace (sika bukyia) constructed for direct smelting application works on charcoal and very high temperatures of over $1300^{\circ} \mathrm{C}$ were attainable during combustion. Charcoal burns to give a relatively uniform temperature range and when packed, it provides a stable bed for the crucibles. Palm kernel shells may serve as a substitute for charcoal as it is cheap, has a high calorific value. The response of miners who witnessed the demonstrations was very positive, and they are eager to give this method a try. Some volunteered and gave their gold bearing black sands for smelting.

\section{Acknowledgements}

The authors are grateful to the European Union for sponsoring the project. Contributions from Kevin D'Souza of Wardell Armstrong LLP, UK and Wilson Mutagwaba, of MTL Consulting Company Limited, Tanzania are gratefully acknowledged.

\section{References}

Anon (1999) Assistance in Assessing and Reducing Mercury Pollution Emanating from Artisanal Gold Mining in Ghana - Phase I, www.natural-resources.org/minerals/CD/docs/unido/ sub2igoatt6part2.pdf

Anon (2003) Reports on Selected Themes in Natural Resources Development in Africa: Artisanal and Small-scale Mining and Technology Challenges in Africa, UNEA, Third Meeting of the Committee on Sustainable Development.

Anon (2008) Ghana Minerals Commission, http://www.ghana-mining.org/ghweb/en/ma/ mincom.html

Anon (2009) Annual Report, 2008, Mineral Commission of Ghana (self published), Accra, pp.5-13.

Appleton, J.D., Williams, T.M., Breward, N., Apostol, A., Miguel, J. and Miranda, C. (1999) 'Mercury contamination associated with artisanal gold mining on the Island of Mindanao, The Philippines', The Science of the Total Environment, Vol. 228, Nos. 2-3, pp.95-109.

Babut, M., Sekyi, R., Potin-Gautier, M., Tellier, S., Bannerman, W., Casellas, C. and Rambaud, R. (2001) US/GHA/99/128 - Assistance in Assessing and Reducing Mercury Pollution Emanating from Artisanal Gold Mining in Ghana - Phase 1: Part II - Conduct of Surveys on River Systems and overall conclusions, United Nations Development Organization (UNIDO), Vienna.

Babut, M., Sekyi, R., Rambaud, A., Potin-Gautier, M., Tellier, S., Bannerman, W. and Beinhoff, C. (2003) 'Improving the environmental management of small-scale gold mining in Ghana: a case study of Dumasi', Journal of Cleaner Production, Vol. 11, No. 2, pp.215-221. 
Cleland, K. (2008) Financial Evaluation of Small Scale Mining Projects in Ghana - A Case Study, MSc Thesis, University of Mines and Technology, Tarkwa, p.92.

Drasch, G., Böse-O'Reilly, S., Beinhoff, C., Roider, G. and Maydl, S. (2001) 'The Mt. Diwata study on the Philippines 1999 - assessing mercury intoxication of the population by small scale gold mining', The Science of the Total Environment, Vol. 267, Nos. 1-3, pp.151-168.

Hilson, G. and Monhemius, A.J. (2006) 'Alternatives to cyanide in the gold mining industry: What prospects for the future?', Journal of Cleaner Production, Vol. 14, Nos.12-13, pp.1158-1167.

Hilson, G., Hilson, C.J. and Pardie, S. (2007) 'Improving awareness of mercury pollution in small-scale gold mining communities: Challenges and ways forward in rural Ghana', Environmental Research, Vol. 103, No. 2, pp.275-287.

Serfor-Armah, Y., Nyarko, B.J.B., Adotey, D.K., Dampare, S.B. and Adomako, D. (2004) 'The impact of small-scale mining activities on the levels of mercury in the environment: The case of Prestea and its environs', Journal of Radioanalytical and Nuclear Chemistry, Vol. 262, No. 3, pp.685-690.

Styles, M.T., Amankwah, R.K., Al Hassan, S. and Nartey, R.S. (2009) 'The identification and testing of a method for mercury-free gold processing for artisanal and small-scale gold miners in Ghana', International Journal of Environment and Pollution, this volume.

Tschakert, P. and Singha, K. (2007) 'Contaminated identities: Mercury and marginalization in Ghana’s artisanal mining sector', Geoforum, Vol. 38, No. 6, pp.1304-1321.

\section{Note}

${ }^{1}$ The ThermEX glass retort is a German made retort introduced by UNIDO as part of its intervention programmes in the small-scale gold sector. 